\title{
BANK MONITORING AS AN EXTERNAL GOVERNANCE MECHANISM AND THE BORROWERS' FIRM VALUE
}

\author{
Alexandra Ryan Ahmad Dina \\ Universitas Indonesia \\ Ancella Anitawati Hermawan \\ Universitas Indonesia ${ }^{1}$
}

\begin{abstract}
The objective of this research is to examine the effect of bank monitoring as an alternative of corporate governance mechanisms on the borrowers' firm value. The strengths of bank monitoring on the borrowers are measured based on the magnitude of the bank loan, the size of the loan from banks with high monitoring quality, the length of a bank loan outstanding period, and the number of lenders. The research hypotheses were tested using multiple regression model with a sample of 230 companies listed in Indonesia Stock Exchange during 2009. The empirical results show that only the size of the loan from banks with high monitoring quality and the number of lenders significantly influences the borrowers' firm value. These findings imply that only banks with high monitoring quality could play an important role in the corporate governance and therefore increasing the firm value by their monitoring function. Furthermore, bank monitoring is less effective if a company borrows from many banks, and therefore decreasing the firm value.
\end{abstract}

Keywords: corporate governance, bank monitoring, bank loan, firm value.

\section{INTRODUCTION}

The concept of good corporate governance has been formally introduced in Indonesia after the 1998 economic crisis. The basic

\footnotetext{
${ }^{1}$ Ancella A. Hermawan, Universitas Indonesia, Jl. Salemba Raya no. 4, Jakarta 10430, Indonesia, phone: +62-21-3103976 ( ancella_hermawan@yahoo.com).
} 
principle of corporate governance is to ensure the fulfillment of the company's responsibility to the company's stakeholders. Internal corporate governance structure, such as the board of commissioners ${ }^{2}$ and audit committee, has been set up in companies in order to have a controlling function for management decisions and actions. Agency problems between shareholders and management, between creditors and shareholders, and between majority shareholders and minority shareholders, are expected to be minimized with the existence of good corporate governance. Corporate governance enhances effective decision-making control, prevent opportunistic actions that are inconsistent with the interests of the stakeholders, and reduce the information asymmetry between management and stakeholders of the company. One corporate governance mechanisms that can be used to address the agency problem is to perform both internal and external monitoring (Jensen and Meckling, 1976). External monitoring is primarily done by external auditors, but creditors can also play an important role in monitoring by external parties.

In line with the objective of corporation to maximize shareholders' wealth by increasing firm value, many companies use debt financing combined with equity financing to get the interest tax shield benefit (Modigliani and Miller, 1963). The source of debt financing could be from the capital market by issuing bonds, or from financial institutions. The bond market in Asia is relatively undeveloped; therefore most large companies in Asia including Indonesia are still use bank loans as their source of debt financing (Nam and Nam, 2004). When a company uses bank loans as its source of financing, the bank becomes one of the company's stakeholders, who have the interest to monitor any activity undertaken by the company's management. One of the main reasons why banks do the monitoring activity is to reduce the credit risk (Ahn and Choi, 2009). Agency problems could arise between creditors and shareholders, because each of them has different contingent claim amount on the firm value.

\footnotetext{
${ }^{2}$ Indonesia adopts a two-tier system in its corporate governance structure, where there is a complete distinction between executive function and monitoring function. Therefore, the monitoring role is the responsibility of board of commissioners, and the managing role is the responsibility of board of directors or board of executives. Board of commissioners has similar roles as board of directors in the one-tier system companies in other countries.
} 
Therefore, creditors need to make sure that the funds obtained by the company are used appropriately as planned and efficiently. In this case, the bank will do a monitoring function, which is somewhat similar to the function of board of commissioners and audit committee in corporate governance. If the management could act prudently with the existence of bank monitoring, the firm value should increase eventually

This study discusses the influence of the monitoring role of banks as an alternative of corporate governance mechanisms to increase the value of a company that has a bank loan. This study refers to previous research conducted by Ahn and Choi (2009) and Hermawan (2009). Both studies have tried to examine the role of bank monitoring in the borrowers' quality of earnings. Hermawan (2009) measured the level of bank monitoring based on the total amount of loan from banks that are considered having good monitoring capability on their borrowers. Ahn and Choi (2009) used the magnitude of bank loans, lead bank reputation, length of bank loan, and the number of bank lenders to measure the level of bank monitoring. In contrast to Ahn and Choi (2009) and Hermawan (2009), this study examines the influence of bank monitoring as an alternative of corporate governance mechanisms on the firm value. The objective of this study is to provide empirical evidence in Indonesia regarding the possibility of external corporate governance mechanisms conducted by the bank as one of the company's stakeholders to increase the firm value.

\section{LITERATURE REVIEW}

\section{The Role of Bank Monitoring as Corporate Governance Mechanisms}

Basically, in some countries where the economic system is characterized by bank financing as an external source of financing, such as Japan and Germany, corporate governance mechanisms can also be done by the banks through direct ownership or financing mechanisms (Charkham, 1995). Moerland (1995) showed that agency problem is reduced in such situation. Some literatures in financial economics explore how banks run their unique role and how relationships between the banks and the companies affect the company's business. However, there are still only few empirical 
evidences about the monitoring role of banks as one of corporate governance mechanism (Shleifer and Vishny, 1997). Byers et al. (2008) convey some important insights about the extent to which the bank can replace the monitoring of internal and external corporate governance mechanisms. They found the existence of positive association between loan announcements and the borrowers' excess returns.

The objective of bank monitoring is to reduce the banks' credit risk by preventing borrowers' opportunistic behavior both before and after the loan is approved. Prior to the loan approval, the borrowers can take opportunistic actions to be able to have higher borrowing capacity, lower interest rates, and lower contract costs (Mishkin and Eakins, 2003). Borrowers have the possibility to manage their earnings to achieve such objectives. Recently, managing earnings are not only done by managing discretionary accruals in the financial statement reporting, but also through real activites. Roychowdury (2006) states that there are three methods based on real activities that can be used by management to manipulate earnings: (1) Revenue manipulation by giving price discount or soft credit sales to boost up sales; (2) Reduction in discretionary expenditures such as research and development cost, human resources development cost, marketing costs, maintaince cost, etc.; (3) Overproduction. Graham et al. (2005) found that management tend to use real activities manipulation than accruals to manage their financial reporting. Therefore, borrowers' opportunistic behavior to manage their earnings could possibly destroy the company's value in the future. After the loan is realized, borrowers still have an incentive to perform opportunistic actions. One of the reasons is to avoid default due to inability to meet the debt covenants. Some covenants are accounting-based measured, which depends on the borrowers' financial performance. Generally, violations of debt covenants would have a negative impact such as higher interest rates, obligations for early repayment of loans, and additional restrictions on the borrowers' activities (Beneish and Press, 1993).

Banks have specific interest to reduce the possibility of borrowers take such opportunistic actions that can reduce their repayment capacity. This bank monitoring will complement the monitoring function of internal corporate governance mechanism. Hopefully this 
will have positive impact to borrowers' firm value. Treacy and Carey (1998) found that major banks in the United States are using qualitative and quantitative measurements for evaluating their credit risk. Their study showed that banks examine borrowers' risk factors such as the financial statements reliability, the management quality, and the financial conditions. These findings support the importance of effective monitoring on management actions in order to achieve a good corporate governance.

Unlike individual creditors and other specialized agencies such as auditors, banks have a comparative advantage in monitoring their borrowers, because the banks have a low cost of delegation, economies of scale in monitoring activity, and the ability to access inside information (Ahn and Choi, 2009). Diamond (1984) and Fama (1985) focused their research on the banks' ability to get better information about borrowers, and therefore banks have some advantages in carrying out the monitoring function. Diamond (1984) developed a theory about the delegation of monitoring, which prove the superiority of the banks in term of the cost of delegation. While Fama (1985) shows that banks have informational advantages over other financial intermediaries.

\section{The Effect of Corporate Governance on Firm Value}

Many previous studies focused on the effect of corporate governance on the firm value. Some studies used the ownership structure as the corporate governance mechanisms. Jensen and Meckling (1976) suggested that the greater ownership by management could reduce the agency problem between management and shareholders. However, Demsetz and Villalonga (2001) found that there was no significant association between management shares ownership and company's performance.

Arsjah (2002) investigated the influence of corporate governance on firm's performance. Firm's performance is measured by Price to Book Value (PBV) ratio and corporate governance is measured based on corporate governance index published by Credit Lyonnais Securities Asia (CLSA) and Indonesian Institute of Corporate Governance (IICG). The result of her study is still mixed. Corporate governance has some influence on company's performance only for the sample that used corporate governance index from CLSA, but for 
the sample that used corporate governance index from IICG there was no significant influence. Utama and Utama (2005) conducted a study on the practice of corporate governance and value creation of companies in Jakarta Stock Exchange. Corporate governance practices are measured by two measurements, i.e. the Corporate Governance Performance Index (CGPI) and the Corporate Governance Score (CGS). The company's value is measured by the ratio of Economic Value Added (EVA) Spread and Market Value Added to Invested Capital (MVA/IC). This study also showed mixed results. Corporate governance measured by CGPI positively affects the firm's value measured by EVA spread, although the association is still marginally significant. However, the association is negatively significant when firm's value measured by MVA/IC. If corporate governance is measured by CGS, it has a significant and positive effect on firm's value measured by MVA/IC, but it does not have any effect on firm's value measured by EVA Spread.

Black et al. (2003) proved the association between corporate governance and the firm value in Korea. This study used a Corporate Governance Index (CGI) as a proxy for corporate governance and Tobin's Q as a measure of firm value. The result showed statistically strong evidence that firms with higher CGI will have higher Tobin's Q. Silveira and Barros (2006) investigated the influence of the quality of corporate governance on market value of over 154 Brazilian companies listed on São Paulo Stock Exchange (Bovespa) in the year 2002. The quality of governance is measured by CGI, and the company's market value is measured by Tobin's Q and Price to Book Value ratio. The findings also show that quality of corporate governance has positive and significant impact on the company's market value.

\section{The Effect of Bank Monitoring on Borrowers' Firm Value}

Most studies of bank monitoring associated with syndicated loans, focusing more on the information asymmetry between the lead bank with the syndicated participants (Dennis and Mullineaux, 2000, Lee and Mullineaux, 2004, Champagne and Kryzanowski, 2007; Sufi, 2007). However, these studies did not test the monitoring role of banks in corporate governance. Ahn and Choi (2009) provide empirical evidence regarding the role of bank monitoring on the borrowers' earnings management behavior. Their study found that 
earnings management behavior decreases if the strength of bank monitoring increases. The strength of bank monitoring is measured by the amount of bank loans, reputation (rank) of lead banks, length of bank loans, and the number of lenders. The results showed that the amount of bank loans, reputation (rank) of lead bank, and length of bank loan have negative effects on borrowers' earnings management behavior, but the number of lenders has no significant effect. This result implies that bank monitoring has an important role just like the monitoring function of Board of Commissioners and Audit Committee as the company's internal governance structure. Therefore bank monitoring could also contribute in creating good corporate governance that will create firm value.

Hermawan (2009) also conducted a study to examine the effect of bank monitoring role on the earnings informativeness measured by the earnings response coefficient (ERC). The proxy for bank monitoring effectiveness is the amount of loan from banks with good monitoring quality. Banks that are considered having good monitoring quality if the banks meet all the three conditions (1) Have large assets, i.e. above Rp 1 trillion; (2) Have Non Performing Loans < 5\%; and (3) Have a rating of "very good" and "good" in bank performance rating conducted by InfoBank magazine (2007). This study used a multiple regression model with 357 data observations (firm-year) of companies listed on the Indonesia Stock Exchange during the years 2006-2007. The result reveals that bank monitoring does not have any significant influence on the earnings informativeness. However, the earnings response coefficients (ERC) of companies with larger amount of loan from the bank with a good monitoring quality are higher than of companies with smaller loan from banks with good monitoring quality. Therefore, investors may have more confidence on corporate governance of companies that have borrowings from banks with good monitoring quality, and bank monitoring could be one of the corporate governance mechanisms to increase the firm value.

The analogy that the role of banks monitoring can influence the increase of firm value is supported by Byers et al. (2008) who found the effect of loan announcement on the firm value associated with the characteristics of the borrowers' corporate governance. By using a sample of more than 800 commercial loan announcements during the period of 1980-2003, they found that the loan announcement has a 
positive effect on the borrowers' firm value if the borrowers have weak internal corporate governance. However, several other studies that specifically discuss the effect of bank monitoring on the performance and value of the company provided conflicting results (Degryse et al., 2008). Weinstein and Yafeh (1998) found that the relationship between banks and borrowers does not lead to borrowers' profitability or higher growth. Their explanations for their findings are: (1) the cost of capital will increase due to higher interest rates paid to the banks; (2) banks are more risk averse and more conservative in their investment policies, therefore it can reduce the borrowers' growth prospect.

In contrast, Kang et al. (2000) proved that the relationship between banks and companies can facilitate investment policies that can increase shareholders' wealth. Shepherd et al. (2008) also found positive and significant relationship between firm value and the existence of bank loan, especially in companies with high agency cost. By using the Governance Index (G-index) as a measure of managerial entrenchment and Tobin's Q as a measure of corporate value, they prove that the emergence of free cash flow as a result of the bank monitoring can increase the borrowers' firm value. Furthermore, Van Overfelt et al. (2006) also provide empirical evidence regarding the effect of bank affiliation on the performance and risk of bank-affiliated companies. With a sample of 129 public companies in Belgium, they found that the bank affiliation has a positive impact on the ratio of market-to-book and return-on-assets. Bank's level of involvement has a positive effect on company performance and can significantly reduce the volatility of the returnon-assets. The yield on stocks measured by the Sharpe ratio also showed a better performance for bank-affiliated companies.

\section{Hypothesis Development}

In general, the purpose of this study is to have an empirical evidence of how bank monitoring on the borrowers can be considered as an alternative of corporate governance mechanisms to improve the borrowers' firm value. The strength level of the monitoring function assumed to be influenced by the magnitude of the bank loans, the size of loans from banks with high monitoring quality, the bank loan outstanding period, and the number of lenders. 


\section{Magnitude of Bank Loans}

Banks should be willing to put greater attention to borrowers with higher amount of loan because the borrowers' credit risk should be higher. Khalil and Parigi (1998) showed that the increasing amount of the loan can be a signal for banks to give greater attention in monitoring. Kang et al. (2000) stated that the large amount of borrowers' bank loans is positively associated with the banks' motives to conduct monitoring activities. While Lee and Mullineaux (2004) argued that in the case of syndicated loans, banks that have a larger portion in the syndicated loan would have stronger motives to monitor than the other banks. In general, previous studies showed that banks will enhance their monitoring power when banks provide larger loans to a borrower. Ahn and Choi (2009) found that borrowers' earnings management decreases as the size of the loan increases, which indicates that the banks monitoring function becomes more effective as the size of loans of the borrowers increases. An effective monitoring should induce management to take actions that are best for the company. Therefore, the first hypothesis of this study is:

Hla: The size of a company's bank loans has a positive effect on its $P B V$ ratio.

\section{Bank Monitoring Quality}

The role of bank monitoring will be effective if and only if the bank has the capability to do a good monitoring function. One of the factors that could affect the level of monitoring quality is the bank's financial performance. The bank's financial performance could reflect how the bank's management manages the business as financial intermediaries. If banks can manage their credit optimally, by having an effective monitoring on the borrower not only prior to but also after the credit approval, they will achieve an excellent financial performance. Therefore, financial performance indicators and ratings could be used as a standard of bank monitoring quality. Hermawan (2009) refers to the banks performance ratings published by InfoBank (2007) to consider the banks monitoring quality. The result showed that the higher proportion of loans in a company granted by banks that have high monitoring quality, the quality of earnings reported by the company is better.

Within the framework of a bank's risk management, reputation risk is one of the main factors that determine the ability and credibility of the 
bank in performing monitoring functions. This risk refers to the negative opinion of the banks' depositors, from whom banks will get most of their funding. Ahn and Choi (2009) found that reputation (rank) of the lead bank in a syndicated loan significantly influenced the borrowers' earnings management in an opposite direction. Based on prior studies, bank monitoring function on the borrowers will be more effective if the bank has good monitoring capabilities. Therefore, companies that get loans from banks that have high monitoring quality, assumed to be highly monitored and they are not free to act opportunistically (Hermawan, 2009). In other words, the larger the size of loans in a company granted by banks with high monitoring quality, the more effective the bank monitoring on the borrowers. Therefore, the second hypothesis of this study is:

H2a: Companies with large size of loans from banks that have high monitoring quality have $P B V$ ratio higher than any other company.

\section{Length of Bank Loans Outstanding Period}

Rajan and Winton (1995) argued that the existence of debt covenants resulting from long-term loans in a company will provide incentives for banks to increase the strength of monitoring, especially when the covenants are costly. Also, banks will gain more information if they have a longtime relationship with the borrowers (Ongena and Smith, 1998). The presence of long-term loans can reduce the duplication of monitoring costs incurred by banks (Dennis and Mullineaux, 2000). In general, previous studies suggest that the incentives of banks to conduct monitoring activities will increase with the longer loan period. According to Ahn and Choi (2009), the bank monitoring function could be more effective if the outstanding period of the loan is longer. Therefore, the third hypothesis of this study is:

$H 3 a$ : The length of a company's bank loans outstanding period has a positive effect on its $P B V$ ratio.

\section{Number of Lenders}

Syndicated loan is one of the sources of external debt financing available for a company. Compared to loans from a single bank, syndicated loans can offer a better deal for companies, i.e. larger loan amount, and lower cost of debt (Ross et al., 2010). From the perspective of the bank monitoring role, in a syndicated loan the process of credit analysis and risk asessment is done not only by the 
lead bank, but by all the participating banks (Fraser et al., 2001). Therefore, syndicated loans provide a collective monitoring which could result in more intensive monitoring. Ahn and Choi (2009) used the total number of banks involved in syndicated loans as a proxy of number of lenders. They found that the number of lenders has no significant association with the firm's earnings management. In contrast to Ahn and Choi (2009), this study does not focus on syndicated loans due to small number of sample firms (19 out of 230 companies) that use syndicated loans. This study used the number of banks involved in financing a specific company. Based on the same arguments as Ahn and Choi (2009), it can be assumed that if a company has loans from more than one bank, then more banks are interested to perform monitoring functions. Thus the monitoring intensity is expected to increase with the increasing number of banks that provide loans to a company. Therefore, the fourth hypothesis of this study is:

H4a: The number of banks that provide loans to the company has a positive effect on its $P B V$ ratio.

\section{RESEARCH METHOD}

\section{Research Model}

The model used in this study is based on the models of Ahn and Choi (2009) and Hermawan (2009):

$$
\begin{aligned}
\text { PBV }_{\mathrm{i}}= & \beta_{0}+\beta_{1} \text { MAGNITUDE }_{\mathrm{i}}+\beta_{2} \text { DMONQUAL }_{\mathrm{i}}+\beta_{3} \text { LENGTH }_{\mathrm{i}}+ \\
& \beta_{4} \text { NLENDER }_{\mathrm{i}}+ \\
& \beta_{5} \text { ROE }_{\mathrm{i}}+\beta_{6} \text { GROWTH }_{\mathrm{i}}+\beta_{7} \text { RISK }_{\mathrm{i}}+\beta_{8} \text { SIZE }_{\mathrm{i}}+\beta_{9} \\
& \text { LEVERAGE }_{\mathrm{i}}+\varepsilon_{\mathrm{i}}
\end{aligned}
$$

Where:

$\mathrm{PBV}_{\mathrm{i}}$

MAGNITUDE $_{\mathrm{i}} \quad$ : The ratio of the amount of bank loans to total assets of firm $i$ at the end of the study period.

DMONQUAL $_{i} \quad$ : Dummy variables (1.0) with a value of 1 if firm $i$ at the end of the study period have the amount of borrowings from the bank with high monitoring quality greater than or equal to the median, and 0 if otherwise. 
LENGTH $_{\mathrm{i}}$

NLENDER $_{i}$

$\mathrm{ROE}_{\mathrm{i}}$

GROWTH $_{\mathrm{i}}$

RISK $_{\mathrm{i}}$

SIZE $_{\mathrm{i}}$

LEVERAGE $_{\mathrm{i}}$
: Average loan outstanding period of firm $i$ at the end of the study period.

: The number of banks related to the outstanding loans of firm $i$ at the end of the study period.

: Return on Equity, the ratio of earnings to book value of equity of firm $i$ at the end of the study period.

: The growth rate of the firm i measured by sales growth rate at the end of the study period.

: Firm risk measured by the beta of firm $i$ at the end of the study period.

: Firm size measured by total sales of firm $i$ at the end of the study period.

: The ratio of total liabilities to total assets of firm $i$ at the end of the study period.

\section{Population and Sample}

The population of this study consists of all companies listed on the Indonesia Stock Exchange (IDX) in 2009. Using a purposive sampling method, there are 230 firms that meet all the criteria to be the sample for this study. Table 1 shows the sample determination in this study.

\section{RESULTS AND DISCUSSION}

\section{Descriptive Statistics}

The descriptive statistics of the variables used are presented in Table 2. Data that is considered as outliers i.e. has the value higher or lower than 3 (three) standard deviation from the mean, has been winsorized. Based on Table 2, the average PBV ratio of the sample is 1.6993. It indicates that most of the companies used in the sample have created firm value, although still relatively small becasue the average PBV ratio is less than 2.00. Besides, there are some companies that have PBV ratio lower than 1.00 , meaning that those companies have not created value and therefore their market performance is poor. 
Table 1. Determination of Sample

\begin{tabular}{|c|l|c|}
\hline Step & \multicolumn{1}{|c|}{ Sample Criteria } & $\begin{array}{c}\text { Number of } \\
\text { Companies }\end{array}$ \\
\hline 1 & $\begin{array}{l}\text { Companies listed on the Indonesia Stock } \\
\text { Exchange (IDX) in 2009 }\end{array}$ & 397 \\
\hline 2 & $\begin{array}{l}\text { Companies in financial industry } \\
(67)\end{array}$ \\
\hline 3 & $\begin{array}{l}\text { Companies which have their IPOs in the } \\
\text { year 2009 }\end{array}$ & $(11)$ \\
\hline 4 & $\begin{array}{l}\text { Companies that have negative equity } \\
(19)\end{array}$ \\
\hline 5 & $\begin{array}{l}\text { Companies that have incomplete data } \\
\text { loan in the year 2009 }\end{array}$ & $(8)$ \\
\hline & \begin{tabular}{l} 
Total samples used \\
\hline
\end{tabular}
\end{tabular}

The average magnitudes of bank loans as ratio to total assets is 0.1986. It indicates that the use of bank loans as the source of financing in the sample companies is not dominant. In other words, companies used as the sample in this study have relatively low leverage. From the monitoring quality perspective, there is only $44 \%$ of the sample obtain loans from banks in the category of good monitoring quality. It means that more than half of the sample firms borrow from banks that are considered having low monitoring quality.

Bank loan outstanding period measures the loan elapsed time since the loan is granted by banks. The average bank loans outstanding period is 2.86 years, or aproximately equivalent to 3 years. It indicates that most sample firms may have short-term bank loans only or recently acquired long-term bank loans. The shortest bank loan outstanding period in the sample is 1 year and the longest period is 8 years. The average number of lenders in the sample firms is 3.48 , with the minimum number is 1 lender and the maximum nubmer is 13. It indicates that most companies in the sampel borrows from more that one bank. 
Table 2. Descriptive Statistics

\begin{tabular}{|l|c|c|c|c|}
\hline & Minimum & Maximum & Mean & $\begin{array}{c}\text { Standard } \\
\text { Deviation }\end{array}$ \\
\hline PBV & 0.07 & 5.68 & 1.5655 & 1.4322 \\
\hline MAGNITUDE & 0.00 & 0.70 & 0.1977 & 0.1635 \\
\hline DMONQUAL & 0 & 1 & 0.44 & 0.497 \\
\hline LENGTH (years) & 1.00 & 8.00 & 2.8692 & 1.6341 \\
\hline NLENDER & 1 & 13 & 3.48 & 3.015 \\
\hline ROE (\%) & -99.32 & 64.14 & 7.2422 & 23.3224 \\
\hline GROWTH (\%) & -91.49 & 478.69 & 4.7286 & 61.7330 \\
\hline RISK & -1.505 & 2.460 & 0.6220 & 0.74633 \\
\hline SIZE (million Rupiah) & 1,715 & $30,261,178$ & $3,411,225$ & $6,187,7919$ \\
\hline LEVERAGE & 0.05 & 0.97 & 0.5171 & 0.1989 \\
\hline
\end{tabular}

$\mathrm{PBV}_{\mathrm{i}}$ : value of the firm measured by the ratio of price to book value of equity of firm $i$ at the end of the study period, MAGNITUDE $\mathrm{i}_{\mathrm{i}}$ : size of bank loans measured by the ratio of the amount of bank loans to total assets of company $i$ at the end of the study period, DMONQUAL $L_{i}$ : bank's monitoring quality measured by dummy variables (1.0) with a value of 1 if firm $i$ at the end of the study period has the total borrowing amount from banks with high monitoring of quality greater than or equal to the median, and 0 if otherwise, $\mathrm{LENGTH}_{\mathrm{i}}$ : loan period measured by the average loan outstanding period in company $i$ at the end of the study period, NLENDER $\mathrm{i}_{\mathrm{i}}$ : number of lenders measured by the number of banks relate to the company $\mathrm{i}$ outstanding loan at the end of the study period, $\mathrm{ROE}_{\mathrm{i}}$ : company's profitability measured by the ratio of net earnings before extraordinary items to book value of equity of company $i$ at the end of the study period, GROWTH$H_{i}$ : company's rowth rate measured by the sales growth rate of company $\mathrm{i}$ at the end of the study period, RISK $\mathrm{i}_{\mathrm{i}}$ : company's risk measured by the beta of firm $i$ at the end of the study period, SIZE $\mathrm{E}_{\mathrm{i}}$ : company's size measured by total sales of company $i$ at the end of the study period, LEVERAGE ${ }_{\mathrm{i}}$ : company's capital structure measured by the ratio of total liabilities to total assets of firm $i$ at the end of the study period.

Most companies in the sample have a moderate profitabilty, with average ROE of $6.85 \%$. The leverage of the sample measured by total liabilities to total assets is $51.90 \%$ on average. It indicates that companies tend to have liabilities other than bank loans in a quite significant proportion. The average sample firms' size measured by the total sales is Rp. 3,423,950 million and the average sales growth rate of the sample firms in 2009 is $67.34 \%$.. It indicates that most sample firms are large firms and have a relative high sales growth. RISK variable reflects the firm's risk as measured by beta that company. The average value of the sample firms' beta is 0.6233 , which means that on average the sample firms have a lower risk than the market. However, the low average value of beta can be also due to the inactively traded stock of some companies in the sample during the study period. 


\section{Correlation Analysis}

The result of the correlation analysis is presented in Table 3. The value of the dependent variable (i.e. PBV) has been transformed into $\log$ arithm value (LogPBV) to have a more normal distribution. From the four main variables in the model, only DMONQUAL has a significant positive correlation with $\operatorname{LogPBV}$. It indicates that firms with high amount of loans obtained from banks with high monitoring quality have higher increase in PBV.

LogPBV variable correlates positively and significantly to all the control variables, i.e. ROE, GROWTH, RISK, SIZE, and LEVERAGE. This relationship strengthens the findings from previous studies that profitability, size, growth rate, the level of leverage and risk the company will affect the increased value of the company. The correlation coefficients among all independent variables are relatively small, i.e. below 0.80. Thus, there is low likelihood of multicollinearity problems in the regression output for the research model. 
Table 3. Pearson Correlation Analysis

\begin{tabular}{|c|c|c|c|c|c|c|c|c|c|c|}
\hline & LogPBV & MAGNITUDE & DMONQUAL & LENGTH & NLENDER & ROE & GROWTH & RISK & SIZE & LEVERAGE \\
\hline LogPBV & 1.00 & & & & & & & & & \\
\hline MAGNITUDE & $\begin{array}{r}0.018 \\
(0.788)\end{array}$ & 1.00 & & & & & & & & \\
\hline DMONQUAL & $\begin{array}{c}0.149^{*} \\
(0.024)\end{array}$ & $\begin{array}{r}-0.179 * * \\
(0.006)\end{array}$ & 1.00 & & & & & & & \\
\hline LENGTH & $\begin{array}{r}-0.018 \\
(0.791)\end{array}$ & $\begin{array}{r}0.043 \\
(0.514)\end{array}$ & $\begin{array}{r}0.028 \\
(0.669)\end{array}$ & 1.00 & & & & & & \\
\hline NLENDER & $\begin{array}{c}-0.022 \\
(0.736)\end{array}$ & $\begin{array}{l}0.151^{*} \\
(0.022)\end{array}$ & $\begin{array}{r}-0.423 * * \\
(0.000)\end{array}$ & $\begin{array}{r}-0.059 \\
(0.370)\end{array}$ & 1.00 & & & & & \\
\hline ROE & $\begin{array}{r}0.208 * * \\
(0.001)\end{array}$ & $\begin{array}{r}-0.229 * * \\
(0.000)\end{array}$ & $\begin{array}{c}-0.051 \\
(0.443)\end{array}$ & $\begin{array}{r}-0.018 \\
(0.783)\end{array}$ & $\begin{array}{r}-0.003 \\
(0.961)\end{array}$ & 1.00 & & & & \\
\hline GROWTH & $\begin{array}{c}0.133^{*} \\
(0.045)\end{array}$ & $\begin{array}{c}-0.149^{*} \\
(0.024)\end{array}$ & $\begin{array}{r}0.094 \\
(0.154)\end{array}$ & $\begin{array}{r}0.175 \\
(0.008)\end{array}$ & $\begin{array}{r}-0.110 \\
(0.097)\end{array}$ & $\begin{array}{c}0.143^{*} \\
(0.030)\end{array}$ & 1.00 & & & \\
\hline RISK & $\begin{array}{l}0.151^{*} \\
(0.022)\end{array}$ & $\begin{array}{r}-0.083 \\
(0.212)\end{array}$ & $\begin{array}{r}0.116 \\
(0.079)\end{array}$ & $\begin{array}{r}-0.035 \\
(0.602)\end{array}$ & $\begin{array}{r}0.184 * * \\
(0.005)\end{array}$ & $\begin{array}{c}-0.039 \\
(0.552)\end{array}$ & $\begin{array}{r}-0.074 \\
(0.261)\end{array}$ & 1.00 & & \\
\hline SIZE & $\begin{array}{c}0.319 * * \\
(0.000)\end{array}$ & $\begin{array}{c}-0.131^{*} \\
(0.048)\end{array}$ & $\begin{array}{c}-0.081 \\
(0.223)\end{array}$ & $\begin{array}{r}-0.172 * * \\
(0.009)\end{array}$ & $\begin{array}{r}0.453 * * \\
(0.000)\end{array}$ & $\begin{array}{c}0.301 * * \\
(0.000)\end{array}$ & $\begin{array}{r}0.068 \\
(0.305)\end{array}$ & $\begin{array}{r}0.271 * * \\
(0.000)\end{array}$ & 1.00 & \\
\hline LEVERAGE & $\begin{array}{l}0.131^{*} \\
(0.047)\end{array}$ & $\begin{array}{r}0.534 * * \\
(0.000)\end{array}$ & $\begin{array}{c}-0.135^{*} \\
(0.041)\end{array}$ & $\begin{array}{r}0.032 \\
(0.625)\end{array}$ & $\begin{array}{c}0.207 * * \\
(0.002)\end{array}$ & $\begin{array}{r}-0.173 * * \\
(0.008)\end{array}$ & $\begin{array}{r}-0.039 \\
(0.560)\end{array}$ & $\begin{array}{c}-0.154^{*} \\
(0.019)\end{array}$ & $\begin{array}{c}0.158^{*} \\
(0.016)\end{array}$ & 1.00 \\
\hline
\end{tabular}

* Significant at the level of $\alpha=5 \%$ (2-tailed)

** Significant at the level of level $\alpha=1 \%$ (2-tailed)

Amount in the bracket is the p-value 


\section{Hypothesis Testing Analysis}

\subsection{The Effect of Magnitude of a Company's Bank Loans on the Firm Value}

Based on the regression results in Table 4, the magnitude of bank loans in a company does not have any effect on the firm's value. This result does not support the finding of Ahn and Choi (2009) which states that the increasing amount of bank loans will reduce the borrowers' earnings management. Our finding also does not support Khalil and Parigi (1998) statement that the increasing amount of loan can be a signal for banks to increase the strength of the monitoring of the borrowers. The fact that the size of bank loans has no effect on the firm's value indicates that the banks as creditors still do not give any contribution to the implementation of the company's corporate governance. This suggests that the monitoring role of external parties, in this case specifically banks, as corporate governance mechanisms, is still not as effective as the monitoring role of company's internal governance structure.

Another possible argument of why the magnitude of firm's bank loans does not have any effect on the value of the firm is that not all banks actually perform monitoring functions effectively. Based on the descriptive statistics in Table 2, there is only $44 \%$ of the samples have their loans granted by banks with high monitoring quality. It indicates that even though a firm has used a greater amount of bank loans in its capital structure, but if the banks do not have the capability of good monitoring on their borrowers, then the monitoring function conducted by banks will not contribute to the change in firm's in value. This explanation is consistent with the hypothesis 2 a result that will be discussed next.

Table 4. Regression Output

\begin{tabular}{|l|c|c|c|c|}
\hline & \multirow{2}{*}{$\begin{array}{c}\text { Expected } \\
\text { Sign }\end{array}$} & $\begin{array}{c}\text { Unstandardized } \\
\text { Coefficients }\end{array}$ & \multirow{2}{*}{ t-Statistic } & Sig. \\
\cline { 3 - 3 } & & $\mathrm{B}$ & & \\
\hline (Constant) & & -1.0667 & -4.1459 & 0.0000 \\
MAGNITUDE & + & 0.2189 & 1.1655 & 0.1226 \\
DMONQUAL & + & 0.0963 & 1.7366 & $0.0420^{* *}$ \\
LENGTH & + & 0.0014 & 0.0854 & 0.4660 \\
NLENDER & + & -0.0208 & -2.0143 & $0.0226^{* *}$ \\
ROE & + & 0.0026 & 1.7636 & $0.0396^{* *}$ \\
GROWTH & + & 0.0005 & 1.1730 & 0.1211 \\
RISK & - & 0.0636 & 1.7890 & $0.0375^{* *}$ \\
SIZE & + & 0.0646 & 3.2143 & $0.0008^{* * *}$ \\
LEVERAGE & + & 0.2561 & 1.5511 & $0.0612^{*}$
\end{tabular}




\begin{tabular}{|l|r|l|}
\hline R-squared & 0.2032 & \\
Adjusted R-squared & 0.1706 & \\
Durbin-Watson stat & 2.0442 & \\
F-statistic & 6.2332 & \\
Prob(F-statistic) & 0.0000 & \\
$* * *$ & Significant at level $\alpha=$ & $1 \%$ (one-tailed) \\
$* * \quad$ Significant at level $\alpha=$ & $5 \%$ (one-tailed) \\
$* \quad$ Significant at level $\alpha=$ & $10 \% \quad$ (one-tailed)
\end{tabular}

$\operatorname{LogPBV} \mathrm{V}_{\mathrm{i}}$ : value of company $\mathrm{i}$ measured by logarithm value of price to book value of equity at the end of the study period, MAGNITUDE $\mathrm{i}_{\mathrm{i}}$ : size of bank loans measured by the ratio of the amount of bank loans to total assets of company $i$ at the end of the study period, DMONQUAL $L_{i}$ : bank's monitoring quality measured by dummy variables (1.0) with a value of 1 if firm $i$ at the end of the study period has the total borrowing amount from banks with high monitoring of quality greater than or equal to the median, and 0 if otherwise, $\mathrm{LENGTH}_{\mathrm{i}}$ : loan period measured by the average loan outstanding period in company $i$ at the end of the study period, NLENDER $\mathrm{i}_{\mathrm{i}}$ : number of lenders measured by the number of banks relate to the company $i$ outstanding loan at the end of the study period, $\mathrm{ROE}_{\mathrm{i}}$ : company's profitability measured by the ratio of net earnings before extraordinary items to book value of equity of company $i$ at the end of the study period, GROWTH$H_{i}$ : company's rowth rate measured by the sales growth rate of company $i$ at the end of the study period, RISK $\mathrm{i}_{\mathrm{i}}$ : company's risk measured by the beta of firm $i$ at the end of the study period, SIZE $E_{\mathrm{i}}$ : company's size measured by total sales of company $i$ at the end of the study period, LEVERAGE : $_{\mathrm{i}}$ company's capital structure measured by the ratio of total liabilities to total assets of firm $i$ at the end of the study period.

\section{The Effect of Bank Monitoring Quality on the Firm Value}

Based on the regression results in Table 4, bank monitoring quality has significant influence on the firm's value. This means that the banks' monitoring function on their borrowers really exists and is conducted effectively only if the banks have good monitoring capability. The monitoring conducted by the banks then will contribute as a governance mechanism to increase the firm's value. This finding is consistent with the finding of Ahn and Choi (2009) which states that the borrowers' earnings management will decrease when the loans are from banks with higher rank of reputation. The result of this study also supports Hermawan (2009) who found that companies with larger proportion of loans from the bank with a good monitoring quality will improve the response of investors on companies' earnings reflected on the stock returns. Therefore a good monitoring by the banks could prevent the borrowers to lower the earnings quality, so that investors become more responsive to the earnings information in the market.

This result also supports Billett et al. (1995) which proves that the bank identity indicated by the credit ratings is positively associated 
with the stock returns for companies that have bank loans. The identity of the bank gives a signal to investors about the two things, i.e. the bank knows the level of the borrowers' risk and the bank has the capability of monitoring to ensure that the borrowers' investment decisions and expenditures are increasing the firm's value (Fama, 1985). Therefore, the monitoring role by the banks could be an alternative of corporate governance mechanisms only if the banks have good monitoring capability on their borrowers.

\section{The Effect of the Length of Bank Loans Outstanding Period on the Firm Value}

Based on the regression results in Table 4. the length of the loan outstandidng period has no influence on the firm value. This result is not consistent with the finding of Ahn and Choi (2009) which states that the longer the bank loan period will reduce the borrowers' earnings management, meaning that the bank monitoring should be more effective. One possible argument for the lack of influence of the loan outstanding period to the firm value in this study is because most of the loans obtained by the borrowers have an average elapsed time of 2.8 years, as shown in Table 2. Out of the total samples (230 companies), only 150 companies or about $65 \%$ have long-term loans, and the average elapsed time of 3.3 years. Therefore, the samples in this study may fail to capture the benefit of longer loan period in term of bank monitoring, i.e. long-term relationship between companies and banks that can strengthen the monitoring capacity from the bank perspective. The longer the bank loan period will provide incentives for banks to increase their monitoring efforts (Rajan and Winton, 1995).

\section{The Effect of Number of Lenders on the Firm Value}

Based on the regression results in Table 4, the increase in the number of banks that provide loans to a company will a negative effect on the firm value. This result supports the study of Preece and Mullineaux (1996) who found that increasing the number of banks as the company creditors will significantly decrease the firm value. Their finding were confirmed by the robustness test that provides evidence that when a company received a syndicated loan of over 3 (three) banks in it will have a lower value than firms that have loans from a single bank. The explanation of this finding is that a syndicated loan involves a number of bank participants and in this situation the bank loan would be 
similar to a publicly held bonds where the creditor are numerous and scattered. The monitoring function could become ineffective and it could be more difficult for banks to renegotiate loan terms.

Based on the descriptive statistics in Table 2, the average number of lenders in the samples is 3.47. It supports the statement of Preece and Mullineaux (1996) that if the number of lenders is more than 3 (three) than the firm value will decrease. Our finding in this study implied that bank monitoring becomes ineffective when a company deals with many banks as its source of debt financing, because each bank might rely on other banks to do the monitoring function on their borrowers and does not do the monitoring on their own. However, the result of this study is not consistent with Ahn and Choi (2009) who found no influence of the number of banks in a syndicated loan on the borrowers' opportunistic behavior.

\section{CONCLUSION}

This research examines the effect of bank monitoring as an alternative of corporate governance mechanisms on the borrowers' firm value. The strengths of bank monitoring are measured based on the magnitude of a company's bank loan, the size of a company's loan from the bank with a high monitoring quality, the length of a bank loan outstanding period, and the number of lenders in a company. The empirical results show that the bank monitoring quality and the number of lenders are significantly influence to the borrowers' firm value. However, the magnitude of the company's bank loan and the length of the bank loan period have no significant effect on the borrowers' firm value. These findings imply that only bank with good monitoring quality that could play an important role in the corporate governance of bank-dependent firms, and could give a significant contribution in the company's value creation by their monitoring function. Furthermore, bank monitoring is less effective if the company borrows from more banks and can result in decreasing the firm value.

There are several limitations of this study. The bank monitoring effectiveness is measured by certain proxies and is not based on an actual observation of how the monitoring is conducted by the bank. 
The monitoring quality is also determined by the banks' performance rating done by InfoBank magazine (2010). Therefore, there may be some inaccuracy in the measurement of the bank monitoring quality. Further research should use other measurement to solve these limitations and provide more solid findings regarding the role of banks as external corporate governance mechanisms.

\section{REFERENCES}

Ahn, S., Choi, W., 2009. The role of bank monitoring in corporate governance: evidence from borrowers' earning management behavior. Journal of Banking and Finance 33, 425-434.

Arsyah, Regina J., 2005.The association of corporate governance, firm value and earnings management in Jakarta Stock Exchange. Dissertation, University of Indonesia.

Beneish, M., Press, E., 1993. Costs of technical violation of accounting-based debt covenants. The Accounting Review 68, 233-257.

Billett, M., Flannery, M., Garfinkel, J., 1995. The effect of lender identity on a borrowing firm's equity return. Journal of Finance 50, 699-718.

Black, Bernard S., Jang H., Kim, W., 2003. Does corporate governance affect firm value? Evidence from Korea. Working Papers, www.ssrn.com.

Byers, Steven S., Fields, L. Paige, Fraser, Donald R., 2008. Are corporate governance and bank monitoring substitutes: evidence from the perceived value of banks loan. Journal of Corporate Finance 14, 475-483.

Champagne, C., Kryzanowski, L., 2007. Are current syndicated loan alliances related to past alliances?. Journal of Banking and Finance 31, 3145-3161.

Charkham, J., 1995. Keeping good company: a study of corporate governance in five countries. New York: Oxford University Press. 
Degryse, H., Ongena, S., Tümer-Alkan, G., 2008. Corporate governance: a review of the role of banks. Working paper, Center for Financial Studies - Tilburg University.

Demsetz, H., Villalonga, B., 2001. Ownership structure and corporate performance. Journal of Corporate Finance 7, 209-33.

Dennis, S., Mullineaux, D., 2000. Syndicated loans. Journal of Financial Intermediation 9, 404-426.

Diamond, D., 1984. Financial intermediation and delegated monitoring. Review of Economic Studies 51, 393-414.

Fama, E., 1985. What's different about banks?. Journal of Monetary Economics 15, 29-39.

Fraser, D., Gup, B., Kolari, J., 2001. Commercial Banking: The Management of Risk. South-Western College Publishing, a Division of Thomson Learning, Cincinnati, Ohio.

Graham, J., Harvey, C., Rajgopal, S., 2005. The economic implications of corporate financial reporting. Journal of Accounting and Economics 40, 3-73.

Hermawan, Ancella A., 2009. The effect of board of commissioners and audit committee effectiveness, family ownerships, and bank monitoring role, on earnings quality. Dissertation, University of Indonesia.

InfoBank, 2007. Banks performance rating.

InfoBank, 2010. Banks performance rating

Jensen, M., Meckling, W., 1976. Theory of the firm: managerial behavior, agency costs and ownership structure. Journal of Financial Economics 3 (4), 305-360.

Kang, J., Shivdasani, A., Yamada, T., 2000. The effect of bank relations on investment decisions: an investigation of Japanese takeover bids. Journal of Finance 55 (5), 2197-2218.

Khalil, F., Parigi, B., 1998. Loan size as a commitment device. International Economic Review 39, 135-150.

Lee, S., Mullineaux, D., 2004. Monitoring, financial distress, and the structure of commercial lending syndicates. Financial Management 33, 107-130. 
Mishkin, F., Eakins, S., 2003. Financial Markets and Institutions. Addison Wesley, Boston.

Modigliani, F., Miller, Merton H., 1963. Corporate income taxes and the cost of capital: a correction. American Economic Review 53, 433-443.

Moerland, P.W., 1995. Alternative Disciplinary Mechanisms in Different Corporate Systems. Journal of Economic Behaviour and Organization, 26, 17-34.

Nam, Sang-Woo, Nam, Il Chong, 2004. Corporate governance in Asia: recent evidence from Indonesia, Republic of Korea, Malaysia, and Thailand. Working paper, Asian Development Bank Institute.

Ongena, S., Smith, D., 1998. Bank relationships: a review. Performance of Financial Institutions, Cambridge University Press, forthcoming.

Preece, D., Mullineaux, Donald J., 1996. Monitoring, loan renegotiability and firm value: the role of lending syndicates, Journal of Banking and Finance 20, 577-594.

Rajan, R., Winton, A., 1995. Covenants and collateral as incentives to monitor. Journal of Finance 50, 1113-1146.

Ross, Stephen A., Westerfield, Randolph W., Jaffe, J., 2010. Corporate Finance, 9th edition, McGraw Hill.

Roychowdury, 2006. Earnings management through real activities manipulation, Journal of Accounting and Economics 42, 335370

Shepherd, Joanna M., Tung, F., Yoon, Albert H., 2008. What else matters for corporate governance? The case of bank monitoring, Boston University Law Review 88, 991-1041.

Shleifer, A., Vishny, Robert W., 1997. A survey of corporate governance. Journal of Finance 52 (2), 737-783.

Silveira, Alexandre Di Miceli, Barros, Lucas Ayres B., 2006. Corporate governance quality and firm value in Brazil. Working Paper, www.ssrn.com. 
Sufi, A., 2007. information asymmetry and financing arrangements: evidence from syndicated loans. Journal of Finance 62, 629668.

Treacy, W., Carey, M., 1998. Credit Risk Rating at Large U.S. Banks. Federal Reserve Bulletin, 897-921.

Utama, S., Utama, Cynthia A., 2005. Corporate Governance Practice and Firm Value Creation: Empirical Study in Jakarta Stock Exchange. Usahawan, No.08 Th.XXXIV.

Van Overfelt, W., Annaert, J., Ceuster, M.D., Deloof, M., 2006. Do Universal Banks Create Value? Universal Bank Affiliation and Company Performance in Belgium, 1905-1909. University of Antwerp, SSRN.

Weinstein, D.E., Yafeh, Y., 1998. On the Costs of a Bank Centered Financial System: Evidence from Changing Main Bank Relationships in Japan. Journal of Finance, 53 (2), 635-672. 